\title{
A percepção de variação em semitons ascendentes em palavras isoladas no Português Brasileiro $^{1}$
}

Fernanda Consoni; Waldemar Ferreira Netto

\section{Introdução}

O trabalho aqui apresentado examina a sensibilidade para diferenças na mudança de fO ascendente em palavras isoladas no português brasileiro (PB), baseado no teste feito para o holandês por T'Hart (1981). T'Hart (1981) observa que a frequência fundamental na fala mostra muitas variações rápidas, parte das quais determina a forma percebida do contorno de pitch. Isso implica que a acuidade com a qual os ouvintes percebem mudanças de FO é mais relevante para a compreensão da percepção da entoação do que a já tradicionalmente conhecida diferença de fo na fala.

A entoação é um conjunto de variações de pitch na fala causadas pela variação da periodicidade na vibração das cordas vocais. A entoação pode ser observada de uma variedade de ângulos, todos os quais são igualmente indispensáveis se o que se deseja for entender como a melodia da fala funciona na comunicação humana.

\footnotetext{
${ }^{1}$ CONGRESSO NACIONAL DE FONÉTICA E FONOLOGIA, 10/CONGRESSO INTERNACIONAL DE FONÉTICA E FONOLOGIA, 4, 2008, Niterói.
} 
O teste proposto tem por objetivo verificar qual variação de tom é percebida pelo ouvinte sem a interferência de valores semânticos que poderiam surgir do contexto frasal. Entendemos que em situação de fala normal, as variações tonais são funcionais no contexto daquele enunciado. Entendemos, ainda, que a prosódia se constrói no nível do enunciado, havendo padrões entoacionais previsíveis e reconhecíveis pelos falantes de uma língua. 0 objetivo maior desse projeto é verificar os limites mínimos que a variação tonal pode assumir.

\section{Metodologia}

Os resultados apresentados foram obtidos através de testes de percepção baseados na variação ascendente de semitons em palavras isoladas. Foram apresentados pares de palavras trissílabas, gravados com voz feminina, sempre palavras iguais, para os quais os ouvintes deveriam julgar se havia ou não variação de pronúncia.

Todas as palavras tiverem sua frequência alterada a partir da palavra original de forma a variar de 1 a 4 semitons. Parte das palavras teve todas as sílabas manipuladas e parte teve apenas a sílaba tônica. A manipulação foi feita através da função To Manipulation do Praat considerando uma medida de tempo de $0.03 \mathrm{~s}$ e uma variação de pitch entre 75 e $600 \mathrm{~Hz}$. Os tons obtidos foram manipulados em $6 \%$ acima, obedecendo aos critérios propostos por Pierce (1983).

Os 12 sujeitos envolvidos no teste eram adultos, homens e mulheres, com idade entre 20 e 60 anos, escolarizados. 0 teste consistiu em ouvir os pares de palavras a partir do computador através do Media Player do Windows e anotar em formulário de papel se as palavras dos pares ouvidos tinham a mesma pronúncia ou não. 
A pergunta feita aos sujeitos, As palavras são iguais ou diferentes? permitiu apenas que eles julgassem a qualidade sonora das palavras. Eles foram orientados a prestar atenção na pronúncia da palavra verificando se havia alguma variação.

\section{Apresentação dos resultados}

Os resultados do teste-piloto revelaram que os sujeitos são mais sensíveis a variações que ultrapassem 2 semitons, o mesmo resultado foi obtido por T'Hart (1981) para o holandês.

\begin{tabular}{|l|c|c|c|c|}
\hline & 1st & 2st & 3st & 4st \\
\hline Todas as sílabas manipuladas (TM) & 8 & 34 & 52 & 68 \\
\hline Sílaba tônica manipulada (ToM) & 15 & 32 & 55 & 67 \\
\hline Pares considerados sem variação (SV) & 117 & 74 & 33 & 5 \\
\hline Total & 140 & 140 & 140 & 140 \\
\hline
\end{tabular}

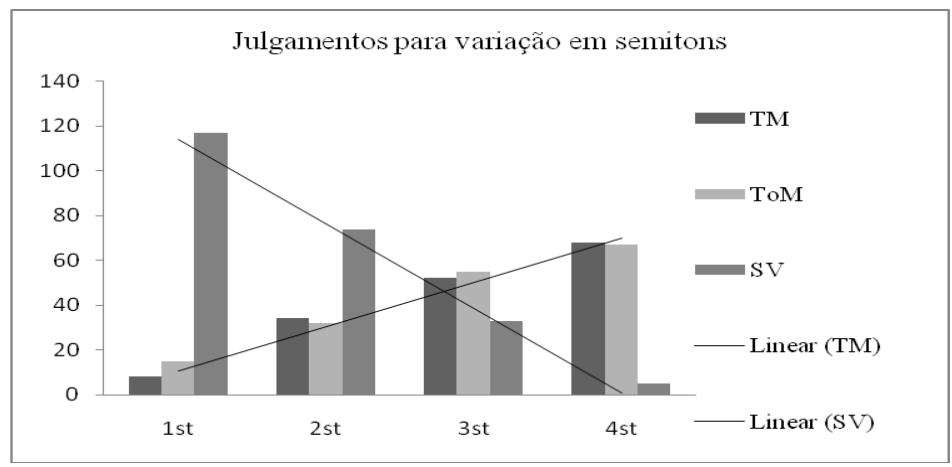

Os resultados demonstraram que há uma correlação perfeita entre a variação de semitons e a marcação dos sujeitos, ( $r 2=$ $0,99)$. Uma sequência de testes qui-quadrado mostrou que os sujeitos percebem com acuidade variações de mais de três ou mais semitons $(p<0,05)$, variações de apenas dois semitons são percebidas de maneira aleatória $(p>0,05)$ e variações de um 
semitom não são percebidas. Os resultados obtidos, como mencionado, foram os mesmos observados por t'Hart (1981) para o holandês, ou seja, o mesmo parâmetro de variação tonal proposto pelo autor pode ser utilizado como parâmetro para a análise do português. Entendemos que tais considerações são preliminares, levando em consideração que os testes devem envolver mais sujeitos. Outro teste em andamento refere-se a variação descendente de tons.

\section{Discussão dos resultados}

Segundo Vaissière, a prosódia compreende todos os níveis superiores do fonema (ou segmento). A substância prosódica é o conjunto de variações na atualização dos fonemas que transmitem informações diferentes daquela dos índices que permitem a identificação dos segmentos. Essas informações prosódicas podem estabelecer diversas relações com a mensagem linguística: elas podem redobrá-la ou modificá-la.

O modelo de perceptual magnet effect (PME) proposto por Kuhl e seus colegas (KUHL; IVERSON, 1995; KUHL, 2000; KUHL et al., 2001) pressupõe a existência de uma forma prototípica fixa, não abstrata, que atua como parâmetro de comparação inicial para todas as demais formas que venham a ser percebidas. Poderíamos supor que as variações perceptíveis em semitons para o português brasileiro teriam seu intervalo de referência a partir de 3 semitons ascendentes.

Ferreira Netto (2006), propõe que a entoação possa ser descrita a partir dos princípios da análise musical, feitas as devidas adaptações a natureza da fala. Tal proposta visa estabelecer uma escala de tons que possa reconhecer a entoação automaticamente através da elaboração de um software que opere tendo como princípio os parâmetros estabelecidos a partir das ferramentas da análise musical. 
Muitas pesquisas e experimentos são necessários para o aprimoramento da proposta de Ferreira Netto (para detalhamento da proposta verificar Ferreira Netto (2006)). A rotina elaborada pelo autor segmenta a entoação em 5 tons, segundo a proposta de Cagliari (1981), estabelecidos três acima ou abaixo de um tom médio. A escala de três semitons foi defendida por t'Hart (1981) como sendo a variação tonal perceptivelmente relevante para os ouvintes do holandês.

No teste aqui proposto pudemos constatar que o mesmo parâmetro de variação tonal proposto por t'Hart poderia ser utilizado como parâmetro para a análise do português. Embora os resultados expressem que há o mesmo padrão de reconhecimento de variação tonal nas duas línguas, esse trabalho só alcançará seus objetivos quando tratar das variações tonais inseridas em enunciados maiores que a palavra. Entendemos que a competência entoacional dos ouvintes só poderá ser testada se, além da forma melódica, for possível estabelecer uma função melódica para o que é reconhecido. 